\title{
Auditor's Competence and Independence as Determinant Audit Quality with Gender as Moderating Variable
}

\author{
I Made Purba Astakoni ${ }^{1^{\star}}$, Ida Bagus Swaputra ${ }^{2}$, Ni Made Satya Utami ${ }^{3}$, Yenny \\ Verawati $^{4}$, \\ ${ }^{1}$ Lecture on Management Program at Sekolah Tinggi Ilmu Manajemen Handayani Denpasar \\ ${ }^{2}$ Lecture on Management Program at Sekolah Tinggi Ilmu Manajemen Handayani Denpasar \\ ${ }^{3}$ Lecture on Management program at Faculty of Economics \& Bussiness at Mahasarswati Denpasar \\ ${ }^{4}$ Lecture on Management program at Faculty of Economics \& Bussiness at Mahasarswati Denpasar
}

\section{ARTICLE INFO}

\section{AIJ use only:}

Received date : 10 June 2020

Revised date : 25 June 2020

Accepted date : 10 July 2020

\section{Keywords:}

Auditor competence

Auditor independence

Audit quality

Gender

Moderating Model

\section{A B S T R A C T}

This study has several objectives: 1) to find out and analyze the effect of auditor competence on audit quality, 2) to know and analyze the effect of auditor independence on audit quality, 3) to know and analyze the role of gender as a moderating effect on the influence of auditor competence on audit quality, 4) to find out and analyze the role of gender as a moderating effect on auditor independence on audit quality. This research was conducted at the Public Accounting Firm (KAP) in Denpasar City. The populations in this study were all auditors in the city of Denpasar, amounting to 112 people. Determination of the sample was done by purposive method, so that the number of samples selected was 53 people. Data collection techniques used was interviews supported by questionnaire with a closed multiple choices. Data analysis used was Partial Least Square (PLS) approach. The results showed that the overall strength of the model was stated to be very good. Hypothesis 1, which states that auditor competence has a significant positive effect on audit quality, can be accepted, Hypothesis 2, which states that auditor independence has a significant positive effect on audit quality, can also be accepted. Through a multi-group analysis it is stated that gender is able to be a moderating variable on the effect of auditor competence over the quality of an audit.Whereas gender testing as a moderating variable on the effect of auditor independence over the quality of an audit has not been tested. 



\section{INTRODUCTION}

Currently the public accounting profession is familiar to the community because almost all private organizations and public sector organizations have used the services of public accountants to audit their financial statements. The management of a company or organization will issue financial statements at the end of each period to account for the company's business activities. Financial statements are important for companies, especially for companies going public. Therefore, insurance services from independent parties are needed to provide assurance that the financial statements presented by the company management are free from material misstatements so that the financial statements can be trusted and can be used as a basis for decision making (Hayati 2011). Financial statements are important things that become a reference for the company's communication facilities with outsiders such as investors who provide information on the results of management performance in managing company resources and displaying financial position in a certain period. The financial statements prepared by companies are used by shareholders, investors, creditors, the government and other stakeholders to make economic decisions so that the information contained in them must be relevant, reliable, and free from material misstatements. Companies in accounting for their business activities and assessing organizational performance are required to submit financial reports prepared in accordance with Financial Accounting Standards (GAAP) and give the right to the public to know all information relating to the company. In order for the financial statements to be relevant, reliable, and free from misstatements, the financial statements must be audited by a third party, namely an external auditor to examine and provide an opinion on the reasonableness of the financial statements which will later be useful to avoid material misstatements in the financial statements.

According to Law number 5 of 2011, public accountant services are services that are used in economic decision making and are widely influential in the era of globalization and have an important role in supporting a healthy and efficient national economy in an effort to increase transparency and quality of information in the financial sector. Public accountant is someone who has obtained permission to provide services as regulated in Law number 5 of 2011. In providing opinion, the auditor

\footnotetext{
* Corresponding author.

E-mail address: astakonimade@gmail.com

Article with open access under license
}

is based on audit work he has done in which parties from outside the company rely more on audited financial statements to make decisions important business decisions because the audited financial statements provide an objective assessment and are free from conflicts of interest (Pektra and Kurnia 2015). In carrying out its audit duties, an auditor must be guided by audit standards set by the Indonesian Public Accountants Association (IAPI), namely general standards, fieldwork standards and reporting standards. In addition to audit standards, an auditor must also comply with a professional code of ethics that regulates professional responsibilities, competence and professional prudence, confidentiality, professional behavior and technical standards for an auditor in carrying out his profession. The great trust of users of audited financial statements and other services provided by public accountants is what ultimately requires public accountants to pay attention to the quality of audits they produce (Agusti and Pertiwi 2013).

There are many factors that can affect an auditor's audit quality. From some previous empirical studies, it can be explained that audit quality is influenced by the variables of competence, independence and motivation (Efendy 2010). Tjun, Marpaung, and Setiawan (2012), Giovani and Rosyada (2019) raised the auditor's competency and independence variables that affect auditor quality. Ningsih and Yaniartha (2013) raised the variable time budget pressure, competence and independence of auditors as independent variables that affect audit quality. Other researchers with independent variables are competence, independence and professionalism of auditors (Agusti and Pertiwi 2013). Deribe and Regasa (2014) in their empirical study in the Ethiopian Commercial Banks raised the independent competence, objectivity, and performance variables that affect audit quality. Anugerah and Akbar (2014) raised the variables of competence, task complexity and professional skepticism that affect audit quality. An empirical study of Tarigan and Susanti (2013) with the variables of competence, ethics, and audit fees as determinants of audit quality. Suyono (2012) in his research raised variable perception, independence, experience, accountability as a determinant of audit quality. Suseno (2013) tried to display the variable independence, audit fees as a determinant of audit quality. Other researchers raised the variable Audit Tenure, Audit Firm Size, Board Independence, Ownership Structure as determinants of audit quality (Enofe et al. 2013). Rahmina and Agoes a (2014) with independent auditor independence variables; tenure audit; audit fee. Jamaluddin and Syarifuddin (2014) present the independent variables of role ambiguity, role conflict, independence that affect audit quality. Sari, Wardoyo, and Laily (2015) raised the variables of independence, professional skepticism, dysfunctional behavior, and professional ethics as determinants of audit quality. 
From several empirical studies, it turns out that it gives different and even contradictory results. The results of Efendy's research (2010), Tjun, Marpaung, and Setiawan (2012), Ningsih and Yaniartha (2013), Agusti and Pertiwi (2013), Anugerah and Akbar (2014), Giovani and Rosyada (2019), the results of the study found competencies have an effect on significant positive effect on audit quality. While the results of the study that showed competency had no effect on audit quality were obtained (Tarigan and Susanti 2013). The results of Bolang, Sondakh, and Morasa (2013) research that showed competence had a significant positive effect on audit quality. The study conducted by Suseno (2013), Enofe et al. (2013), Enofe et al. (2013) Ningsih and

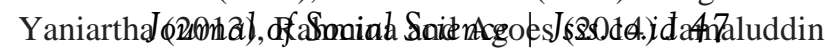
and Syarifuddin (2014), Sari, Wardoyo, and Laily (2015) Giovani and Rosyada (2019), stated that independence had a significant positive effect on audit quality. While the empirical study of Tjun, Marpaung, and Setiawan (2012), Efendy (2010) found auditor independence had no effect on audit quality.

In previous studies there were some limitations that might weaken the results of the research. Some of these limitations include raising gender as an independent variable with nominal measurements. In this study gender is used as a group model, so that its role in the model will be increasingly clear. In a number of previous studies, the auditor's experience, expertise and ability variables were appointed as independent variables, so that in their application it became ambiguous considering that in some concepts it was found that the more experienced an auditor, his expertise would increase and automatically his abilities would increase as well (Pektra and Kurnia 2015) . In this study gender will be treated as a group model and raise endogenous variables of audit quality that are influenced by the competence and independence of auditors in the empirical study at the Public Accounting Firm (KAP) in Denpasar City. The objectives of this study are; 1) to find out and analyze the effect of auditor competence on audit quality, 2) to know and analyze the effect of auditor independence on audit quality, 3) to find out and analyze the role of gender as a moderating effect on auditor competence on audit quality, 4) to find out and analyze the role of gender as a moderating effect on auditor independence on audit quality.

\section{THEORY/CALCULATION (if any)}

\section{Auditing}

Arens and Loebbecke (2009: 17) put forward the definition of auditing as follows: "Auditing is the collection and evaluation of evidence of information to determine and report the level of conformity of the information with established criteria. Auditing must be carried out by someone who is competent and independent. Boynton, Raymon, and Water $(2003$; 5) provide the definition of auditing as: "a systematic process for obtaining and evaluating evidence objectively about the assertions of economic activities and events, with the aim of setting degrees match between these assertions with predetermined criteria and the delivery of the results to the parties concerned. According to Mulyadi (2002: 11) in terms of the public accountant profession, auditing is an objective examination of the financial statements of a company or other organization with the aim of determining whether the financial statements present fairly, in all material respects, financial position and results of operations the company or organization. The audit process is an audit report that expresses opinion in the financial statements that has been presented fairly materially in accordance with generally accepted accounting principles (SAK).

\section{Audit Quality}

Turley and Willekens (2008) state that audit quality is usually related to the auditor's ability to identify material misstatements in the financial statements and his willingness to publish appropriate and unbiased audit reports based on audit results. Furthermore Suseno (2013) in accordance with ISO 8402-1986 (1989) International Standards states that audit quality is a systematic and independent examination to determine whether quality activities and company-related results are in accordance with planned arrangements and whether these arrangements are implemented effectively and appropriately to reach the goal. With regard to services, Boynton et al. (2006) argue that each profession is consistently related to the quality of the services it provides; including auditors where the quality of service is very important to ensure that the profession is accountable to clients, people, and regulations. Audit quality refers to standards with criteria or measures of the quality of implementation and is also related to the objectives to be achieved by implementing related procedures. In short, it can be stated that audit quality is the ability or expertise of the auditor to identify and report significant material misstatements in the client's financial statements.

\section{Auditor Competency}

A competent person is a person who has the skills to do work easily, quickly, intuitively and very rarely or never makes mistakes (Agusti and Pertiwi 2013). Competence as an expertise that is sufficiently explicit can be used to conduct audits objectively (Giovani and Rosyada 2019). Auditors' competencies are auditors with sufficient knowledge and experience who can explicitly conduct audits objectively, carefully and thoroughly. Highly 
educated auditors will have a lot of knowledge about the field they are in, so that they can find out more about various problems. In addition, with sufficient knowledge, auditors will find it easier to keep abreast of increasingly complex developments. So the auditor will be able to produce high quality audits.

\section{Auditor Independence}

Independence means being objective and impartial when doing professional service. The auditor's independence from the company means that the audit is one of the basic requirements to maintain public confidence in the reliability of the audit report (Suseno 2013). Independence adds credibility

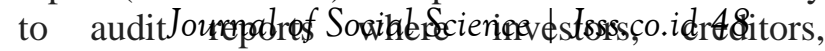
employees, the government, and other stakeholders depend on making decisions about a company. Arens, Elder, and Bessley (2012) suggest that all people involved must maintain independence in the field and independence in appearance to perform professional responsibilities with integrity and maintain objectivity in carrying out their professional responsibilities. Integrity means that a person acts based on conscience regardless of the situation, and the principle of always having objectivity, impartiality and freedom from conflicts of interest (Messier et al. 2008).

\section{Gender}

The term gender is derived from the word gene which means the bearer of male and female embryonic traits. Gender is put forward by social scientists to explain which differences between women and men are innate (biological) as God's creation and which are cultural forms that are constructed, studied and socialized (Utami and Astakoni 2020). This distinction is very important, because so far it is often wrong to mix natural and unchanging human traits with non-natural (gendar) human characteristics that can actually be changuu or changed (Hayati 2011).

\section{The positive effect of auditor competence on audit quality}

Auditors need a competency. Competence is obtained through education and experience (Prihartini, Sulindawati, and Darmawan 2015). Members should not describe themselves as having reliability or experience that they do not have (Mulyadi 2002; 58) Some research on competencies has been done before. Efendy (2010), Tjun, Marpaung, and Setiawan (2012), Ningsih and Yaniartha (2013), Agusti and Pertiwi (2013), Anugerah and Akbar (2014), Giovani and Rosyada (2019), the results of the study showed that competence had a significant positive positive effect on audit quality. While the results of the study that showed competency had no effect on audit quality were obtained (Tarigan and Susanti 2013). The results of Bolang, Sondakh, and Morasa (2013) research which showed competency had a significant positive effect on audit quality. Based on the foregoing, the first hypothesis proposed in this study is H1: auditor competence has a significant positive effect on audit quality.

\section{The positive effect of auditor independence on audit quality}

Mulyadi (2002: 9) defines independence as a state free from influence, not controlled by other parties, not dependent on others and independent public accountants must be public accountants who are not affected and are not influenced by various forces that come from outside the accountant's self in considering the facts that he found in the examination. Previous research on independence was conducted by Suseno (2013), Enofe et al. (2013), Agusti and Pertiwi (2013), Enofe et al. (2013), Ningsih and Yaniartha (2013), Rahmina and Agoes (2014), Jamaluddin and Syarifuddin (2014), Sari, Wardoyo, and Laily (2015), Giovani and Rosyada (2019), which stated that independence had a significant positive effect on audit quality. This means that the higher the independence of an auditor, the better the audit quality will be. While the empirical study of Tjun, Marpaung, and Setiawan (2012), Efendy (2010) found auditor independence had no effect on audit quality. Based on these descriptions, then in this study the following hypotheses can be proposed: $\mathrm{H} 2$; auditor independence has a significant positive effect on audit quality.

\section{METHOD}

\section{Research Design}

The research design used in this study is causal, which is a research model that explains the causal relationships between research variables. The pattern of relationships between latent variables in this study as a result of the relationship of exogenous variables to endogenous variables, then the nature of the variables / constructs in this study are unobserved (latent variables) then an approach with measurement through indicators is used.

\section{Research Sites \& Objects}

This research was conducted in several Public Accounting Firms (KAP) in the city of Denpasar with the research subjects included were all auditors from 12 public accounting offices. The objects or 
variables of this study are audit quality, auditor competence, auditor independence and gender.

\section{Population, Sample and Data Collection}

Population is a combination of all elements in the form of events, things, or people who have similar characteristics that are the center of attention of researchers, and therefore are seen as the universe of research (Ferdinand 2014). The populations in this study were all auditors from 12 public accounting firms in the city of Denpasar, totaling 112 people. Determination of the sample is done by purposive method with predetermined conditions. Meanwhile, the number of samples from the existing population is determined by the Slovin model of 53 auditors. Data collection techniques used in this study was interviews with questionnaires with multiple choices closed. While the measurement scale used is a Likert scale with answer intervals: score 5, answers strongly agree (SS); score 4, answers agree (S); score 3, neutral answer; score 2, answers do not agree (TS); score 1, the answer strongly disagrees (STS).

\section{Operational Definitions and Variable Indicators Audit Quality (Y)}

Audit quality is the auditor's ability or expertise to identify and report significant material misstatements in the client's financial statements. Audit quality in this study was measured by 8 indicators namely KUA1 (audit accuracy), KUA2 (no engineering), KUA3 (without deviations), KUA4 (recommendations for improvement), KUA5 (audible report can be understood), KUA6 (reducing deviations), KUA7 (giving a chance for feedback), KUA8 (monitoring follow-up examinations) (Efendy, 2010)

\section{Auditor competence (X1)}

Auditor competence is an auditor who with sufficient and explicit knowledge and experience can audit objectively, carefully and thoroughly. Competence in this study is measured by 6 indicators namely KOM1 (formal education), KOM2 (according to accounting standards), KOM3 (having insight about organization), KOM4 (expertise), KOM5 (training), KOM6 (have initiative)

(Efendy 2010)

\section{Auditor independence (X2)}

The independence of an auditor in the sense of acting based on conscience regardless of any situation, and the principle of always having objectivity, impartiality and free from conflicts of interest. Independence in this study was measured by 5 indicators namely; INDEP1 (mental attitude free from influence), INDEP2, (not controlled by other parties), INDEP3 (not dependent on others), INDEP4 (inherent honesty), INDEP5 (giving objective consideration) (Mulyadi 2002; 26)

Gender ( $\mathrm{G}$, group model)

Gender in the non-bialogical sense is a social relationship between women and men that is linked to the division of labor and responsibilities, and the way the relationship is built and constructed socially and culturally by the community (Utami and Astakoni 2020). In this study gender will be classified into sub_sample1 (male) and sub_sample2 (female)

\section{Data Analysis Technique}

Descriptive Statistical Analysis

Descriptive analysis is used to describe the characteristics of respondents and the characteristics of respondents' answers to indicators raised from the research construct.

Inferential Statistical Analysis

In this study data analysis uses the Partial Least Square (PLS) approach. In PLS path modeling there are two models namely the outler model and the inner model, where both of these criteria are used in this study. Evaluation of measurement models (measurement models louter models), to measure the validity and reliability of these indicators is convergent validity, discriminant validity, and composite reliability (Sabil 2019). Evaluation of structural models (Structural Model / Inner Model) is a measurement to evaluate the level the accuracy of the model in the overall research, which was formed through several variables along with the indicators. In evaluating structural models there are several approaches including: a) $R$-Square or coefficient of determination, b) $Q$-Square Predictive Relevance (Q2) obtained through the PLS Blinfolding process, with criteria Q2> 0), and c) Goodness of Fit (GoF) (Sabil 2019) provided that $\mathrm{GoF}=0.10$ (Small) $\mathrm{GoF}=0.25$ (Medium) $\mathrm{GoF}=$ 0.36 (Large). Multigroup Analysis (MGA), to examine whether there is a difference in the effect of the auditor's competence construct on audit quality, the difference in the influence of the construct construct on audit quality between male and female groups through the Smith-Satterthwait test path coefficient (Ghozali and Latan, 2015). Based on the value of $\mathrm{t}$ _statistik $\left(\mathrm{t}\right.$ - $\left._{\text {count }}\right)$ then compared with $\mathrm{t}$-table of 1.96 (for alpha 5\%), then it can be concluded that the two paths are significantly different or the discrete variable as a moderating variable. 


\section{RESULTS AND DISCUSSION}

\section{Research Results}

\section{Characteristics of Respondents}

Characteristic of respondent is a description of the whereabouts of respondents involved in research that is based on gender, age, recent education. From the entire sample of company employees totaling 53 people studied, all of them were able to fill out and return the questionnaire given. Based on the number of samples available, the characteristics of research respondents in terms of sex, the majority of respondents in this study were women, namely 30 people and the remaining 23 men. On the basis of the results of the cross tabulation, the distribution can be seen in more detail in Table 1 below

Table 1: Description of Research Respondent Characteristics

\begin{tabular}{|c|l|l|l|l|l|}
\hline Gender & $\begin{array}{l}\text { Interval } \\
\text { Age }(y e a r\end{array}$ & \multicolumn{2}{|c|}{ Respondent Education, people (\% } & Total \\
& Diploma & Bachelor & Post graduat & People $(9$ \\
\hline Male & $<30$ & $6(26,10)$ & 0 & 0 & $6(26,1)$ \\
& $40-49$ & $2(8,70)$ & $3(13,00)$ & $3(13,00)$ & $8(34,80)$ \\
& $>=50$ & 0 & $7(30,40)$ & $2(8,70)$ & $9(39,10)$ \\
& & & & & \\
& Sub total & $8(34,80)$ & $10(43,50)$ & $5(21,70)$ & $23(100,0$ \\
\hline Femal & $<30$ & $2(6,70)$ & $11(36,70)$ & 0 & $13(43,30$ \\
& $40-49$ & 0 & $8(26,70)$ & $3(10,00)$ & $11(36,70$ \\
& $>=50$ & $2(6,70)$ & $4(13,30)$ & 0 & $6(20,00)$ \\
& & & & & \\
& Sub total & $4(13,30)$ & $23(76,70)$ & $3(10,00)$ & $30(100,0$ \\
\hline Total & $<30$ & $8(15,10)$ & $11(20,80)$ & $6(11,30)$ & $19(35,80$ \\
& $40-49$ & $2(3,80)$ & $11(20,80)$ & $2(3,80)$ & $19(35,80$ \\
& $>=50$ & $2(3,80)$ & $11(20,80)$ & $2(3,80)$ & $15(28,30$ \\
& & & & & \\
& Total & $12(22,60$ & $33(62,30)$ & $8(15,10)$ & $53(100,0$ \\
\hline
\end{tabular}

When it is observed from the age side for the majority of male respondents at intervals $>=50$ years of $39.10 \%$, then followed by intervals of 40 49 years with a total of $34.80 \%$ and the lowest with $<30$ years of age of $26.10 \%$. The majority of male respondents received higher education (undergraduate) as much as $43.50 \%$ then followed by diploma and postgraduate education $43.80 \%$ and $21.70 \%$. For the majority of female respondents were at the age interval $<30$ years by $43.30 \%$, then followed by intervals of 40-49 years with the amount of $36.70 \%$ and the lowest with age> 50 years by $20.00 \%$. The majority of female respondents received higher education (undergraduate) of $76.70 \%$ then followed by diploma and postgraduate education $13.30 \%$ and $10.00 \%$.

Inferential Statistics Results

\section{Outler Model Evaluation}

Before conducting multigroup analysis, we must first pass the confirmatory factor analysis (CFA) stage to ascertain whether construct indicators are valid indicators as constructors of latent constructs. After passing through these stages, the next step is to analyze each group to get the path coefficient value for each group and the standard error as input to calculate the Smith-Satterthwait test formula.

\section{Convergent Validity}

Individual indicators are considered valid if they have an outler loading above (> 0.50) and AVE values $>0.50$. The analysis shows the value of outler loading and AVE of all indicators that reflect each construct has an outer loading value> 0.50 and is significant at the 0.05 level and AVE value> 0.50 then all indicators are declared valid as construct indicators.

\section{Discriminant Validity}

Measurement of the validity of the indicators that form latent variables can also be done through discriminant validity. Output discriminant validity is shown through Heterotrait-Monotrait Ratio showing results $<0.90$ so that it is declared valid.

\section{Composite Reliability}

A measurement can be said to be reliable, if the composite reliability and Cronbach alpha have a value greater than 0.70. Composite reliability is a measure of reliability among indicator blocks in the research model. Calculation values show that the composite reliability of all constructs has shown a value of $>0.70$ so that it meets the reliable requirements based on composite reliability criteria.

Inner Model Evaluation

Evaluate the overall model with the analysis tool seen from the side of R-Square (R2) very well, $Q$ Square Predictive Relevance (Q2)>0 and Goodness of Fit (GoF) are in a high position (large) then the overall model is declared very good. Testing the relationship between latent constructs as hypothesized in the study is carried out through the

\begin{tabular}{|l|l|l|l|l|l|l|}
\hline & $\begin{array}{l}\text { Original } \\
\text { Sample } \\
(\mathrm{O})\end{array}$ & $\begin{array}{l}\text { Sample } \\
\text { Mean (M) }\end{array}$ & $\begin{array}{l}\text { Standard } \\
\text { Deviation } \\
\text { (STDEV) }\end{array}$ & $\begin{array}{l}\text { T Statistics } \\
\text { (O/STERR) }\end{array}$ & $\begin{array}{l}\text { P- } \\
\text { Value/ }\end{array}$ & Note \\
\hline $\begin{array}{l}\text { Auditor } \\
\text { Independency } \\
\text { Audit Quality }\end{array}$ & 0,475 & 0,490 & 0,155 & 3,055 & 0,002 & $\begin{array}{l}\text { Not } \\
\text { Signi } \\
\text { ficant }\end{array}$ \\
\hline $\begin{array}{l}\text { Auditor } \\
\text { Competence } \\
\text { Audit Quality }\end{array}$ & 0,471 & 0,460 & 0,159 & 2,946 & 0,003 & $\begin{array}{l}\text { Not } \\
\text { Signi } \\
\text { ficant }\end{array}$ \\
\hline $\begin{array}{l}\text { Auditor } \\
\begin{array}{l}\text { Independency } \\
\text { Audit Quality }\end{array}\end{array}$ & 0,475 & 0,490 & 0,016 & 0,225 & 0,814 & \\
\hline $\begin{array}{l}\text { Auditor } \\
\text { Competence } \\
\text { Audit Quality }\end{array}$ & 0,471 & 0,460 & $-0,012$ & 0,107 & 0,712 & \\
\hline
\end{tabular}


process of re-sampling with the bootstrapping method. Table 2 provides an estimated output for testing the structural model where the expected result is Ho rejected or sig $<0.05$ (or t statistic value $>1,96$ for tests with a significant level of $0.05)$.

Tabel 2: Path Coefficient and Hypotheses Test Result
Satterthwait test, then comparing with the t value of 1.96 (for alpha 5\%). Table 5 presents the complete multigroup comparison test results.

Testing the Role of Gender as a Model Group Table 3 and table 4 are the results of bootstrapping sub_sample1 (male group) and sub_sample2 (female)

Table 3 : Path Coefficient and Standard Error for

\begin{tabular}{|c|c|c|c|c|c|c|}
\hline Relation & $\begin{array}{l}\text { Path } \\
\text { Coefficie } \\
\text { and } \\
\text { Standard } \\
\text { Error }\end{array}$ & $\begin{array}{l}\text { Sub_Samp } \\
\text { Male }\end{array}$ & $\begin{array}{l}\text { Sub_Sample2 } \\
\text { female }\end{array}$ & t-Statistics & t-Table & Note \\
\hline $\begin{array}{l}\text { Auditor } \\
\text { Independen } \\
\rightarrow \text { Audit } \\
\text { Quality }\end{array}$ & $\begin{array}{l}\text { Path } \\
\text { Coefficie } \\
\text { Standard } \\
\text { Error }\end{array}$ & $\begin{array}{l}0,475 \\
0,016\end{array}$ & $\begin{array}{l}0,829 \\
-0,004\end{array}$ & $-21,4644$ & 1,96 & $\begin{array}{l}\text { Not } \\
\text { Signifi }\end{array}$ \\
\hline $\begin{array}{l}\text { Auditor } \\
\text { Competenc } \\
\rightarrow \text { Audit } \\
\text { Quality }\end{array}$ & $\begin{array}{l}\text { Path } \\
\text { Coefficie } \\
\text { Standard } \\
\text { Error }\end{array}$ & 0,471 & 0,119 & 27,0769 & 1,96 & Signifi \\
\hline
\end{tabular}

sub_sample1(male)

Table 4 : Path Coefficient and Standard Error for sub_sample2(female)

\begin{tabular}{|c|c|c|c|c|c|c|}
\hline & $\begin{array}{l}\text { Original } \\
\text { Sample } \\
\text { (O) }\end{array}$ & $\begin{array}{l}\text { Sample } \\
\text { Mean } \\
(\mathrm{M})\end{array}$ & $\begin{array}{l}\text { Standard } \\
\text { Deviation } \\
(\text { STDEV) }\end{array}$ & $\begin{array}{l}\text { T Statistics } \\
\text { (O/STERR) }\end{array}$ & $\begin{array}{l}\text { P- } \\
\text { Value/ }\end{array}$ & Note \\
\hline $\begin{array}{l}\text { Auditor } \\
\text { Independency } \\
\rightarrow \quad \text { Audit } \\
\text { Quality }\end{array}$ & 0,829 & 0,825 & 0,110 & 7,563 & 0,000 & $\begin{array}{l}\text { Signi } \\
\text { ficant }\end{array}$ \\
\hline \multirow[t]{2}{*}{$\begin{array}{l}\text { Auditor } \\
\text { Competence } \\
\rightarrow \quad \text { Audit } \\
\text { Quality }\end{array}$} & 0,119 & 0,123 & 0,130 & 0,913 & 0,362 & $\begin{array}{l}\text { Not } \\
\text { Signi } \\
\text { ficant }\end{array}$ \\
\hline & $\begin{array}{l}\text { Original } \\
\text { Sample }(\end{array}$ & $\begin{array}{l}\text { Sample } \\
\text { Mean } \\
(\mathrm{M})\end{array}$ & $\begin{array}{l}\text { Standar } \\
\text { Error }\end{array}$ & $2,5 \%$ & $97,5 \%$ & \\
\hline $\begin{array}{l}\text { Auditor } \\
\text { Independency } \\
\rightarrow \quad \text { Audit } \\
\text { Quality }\end{array}$ & 0,829 & 0,825 & $-0,004$ & 0,537 & 0,995 & \\
\hline $\begin{array}{l}\text { Auditor } \\
\text { Competence } \\
\rightarrow \quad \text { Audit } \\
\text { Quality }\end{array}$ & 0,119 & 0,123 & 0,005 & $-0,112$ & 0,390 & \\
\hline
\end{tabular}

In accordance with Table 3 and Table 4 which shows the calculations of each group, then the Smith-Satterthwait test calculation can be performed. In accordance with the existing formulation, the value of t-count is -21.4644 for hypothesis 1, and for hypothesis 2 (27.0769). After getting the t-statistic value from the Smith-
The positive effect of auditor independence on audit quality

Hypothesis 2, which states that auditor independence has a significant positive effect on audit quality. In testing, it was found that auditor independence had a positive effect with a coefficient of 0.273 (positive) and p-value 0.007 (or t-statistic 
2.707> 1.96), meaning hypothesis $2(\mathrm{H} 2)$, could be accepted, so the results of this test were consistent with the statement that the higher the independence of auditors, the better the quality of audits produced. This research is in line with empirical studies (Suyono 2012) (Suseno 2013) (Enofe et al. 2013)) Agusti and Pertiwi (2013), Ningsih and Yaniartha (2013), (Rahmina and Agoes 2014), Jamaluddin and Syarifuddin (2014), Sari, Wardoyo, and Laily (2015) Giovani and Rosyada (2019), who stated that independence had a significant positive effect on audit quality. This means that the higher the independence of an auditor, the better the audit quality will be. While the results of this study are not in line with empirical studies (Tjun, Marpaung, and Setiawan 2012), (Efendy, 2010) found auditor independence has no effect on audit quality.

Multigroup testing (moderating effect) based on gender

Testing the role of gender as a moderating effect on auditor competence on audit quality.

The role of gender as a moderating variable on the effect of auditor competence on audit quality can be seen from the t-statistic value of the SmithSatterthwait test of 27.0769> 1.96 (for alpha 5\%), so it can be said that the two paths (in terms of sub_sample1 and sub_sample2) differ significantly or the gender is a variable moderating.

Testing the role of gender as a moderating effect on auditor independence on audit quality

The role of gender as a moderating variable on the effect of auditor independence on audit quality. This can be seen from the t-statistic value of the SmithSatterthwait test of $-21.4644<1.96$ (for alpha 5\%), so it can be said that the two paths (in terms of sub_sample1 and sub_sample2) are not significantly different or gender not as a moderating variable.

\section{CONCLUSION}

\section{Conclusions}

The overall strength of the model by looking at the coefficient of determination, Q-Square Predictive Relevance and Goodness of Fit (GoF) is stated to be very good.

Hypothesis 1, which states that auditor competence, has a significant positive effect on audit quality. In testing, it was found that auditor competence had a positive effect with a coefficient of 0.672 (positive) and a p-value of 0,000 (or t-statistics 7,411> 1.96), meaning hypothesis $1(\mathrm{H} 1)$ was acceptable,

Hypothesis 2, which states that auditor independence has a significant positive effect on audit quality. In testing, it was found that auditor independence had a positive effect with a coefficient of 0.273 (positive) and $\mathrm{p}$-value 0.007 (or t-statistic
2.707> 1.96), meaning hypothesis 2 (H2), acceptable

Through multi-group analysis it is stated that gender is able to be a moderating variable on the effect of auditor competence on audit quality. Based on the tstatistic value of the Smith-Satterthwait test of $27.0769>1.96$ it can be said that the two paths are significantly different, so that gender is tested as a moderating variable. Meanwhile, gender testing as a moderating variable on the effect of auditor independence on audit quality has not been tested.

Recommendations

Based on sub-sample testing, it can be seen that the role of gender in the model has not been able to be a moderating variable, it is hoped that the next researcher can find other variables that are uncontrollable, so that it is closer to the moderating variable. Future researchers are expected to be able to expand their research subjects, bearing in mind that this study only involves public accounting firms in the city of Denpasar. In terms of the constructs raised it still needs to be developed considering that conceptually there are many determinants of audit quality from auditors.

\section{REFERENCES}

1. Agusti, Restu, and Nastia Putri Pertiwi. 2013. "Pengaruh Kompetensi, Independensi, Profesionalisme Terhadap Kualitas Audit (Studi Empiris Pada Kantor Akuntan Publik Se Sumatra)." Jurnal $\begin{array}{llll}\text { Ekonomi } & 21 & \text { (3): } & 1-13 .\end{array}$ https://doi.org/10.22441/tekun.v8i1.5528

2. Anugerah, Rita, and Sony Harsono Akbar. 2014. "Pengaruh Kompetensi, Kompleksitas Tugas Dan Skeptisme Profesional Terhadap Kualitas Audit." Jurnal Akuntansi 2 (2): 139-148. https://doi.org/10.1016/j.jaap.2015.03.007.

3. Arens, A A, and J K Loebbecke. 2009. Auditing; An Intergratied Approach. 7thed. New Jersey: Prentice Hall,Inc

4. Arens, A, RJ Elder, and Bessley. 2012. Auditing And Assurance Services: An Integrated Approach. Pearson: Pearson Prentice Hall.

5. Bolang, Marietta Sylvie, Jullie J. Sondakh, and Jenny Morasa. 2013. "Pengaruh Kompetensi, Independensi Dan Pengalaman Terhadap Kualitas Audit Aparat Inspektorat Kota Tomohon Dalam 
Pengawasan Pengelolaan Keuangan Daerah." Accountability 2 (1): 151-63. https://doi.org/10.32400/ja.2352.2.1.2013. 151-163.

6. Boynton, WC, NJ Raymon, G Walter, and Kell. 2006. Modern Auditing. Edited by D Richard. 8thed. USA. Boynton, William C, Johnsop Raymon, and G Keli Water. 2003. Modern Auditing. Edisi Terj. Jakarta: Erlangga

7. Deribe, Wubishet Jemaneh, and Dereje

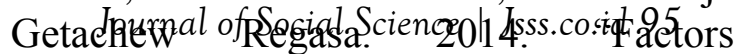
Determining Internal Audit Quality: Empirical Evidence from Ethiopian Commercial Banks." Research Journal of Finance and Accounting 5 (23): 86-95.

8. Efendy, Muh. Taufiq. 2010. "Pengaruh Kompetensi, Independensi, Dan Motivasi Terhadap Kualitas Audit Aparat Inspektorat Dalam Pengawasan Keuangan Daerah." Universitas Diponogoro. https://doi.org/10.1017/CBO97811074153 24.004

9. Enofe, Augustine O, Chijioke Mgbame, Adeyemi Aderin, and Obehioye U Ehioshio. 2013. "Determinants of Audit Quality in the Nigerian Business Environment." Research Journal of Finance and Accounting 4 (4): 36-44

10. Ferdinand, Augusty. 2014. Structural Equation Modeling Dalam Penelitian Manajemen Aplikasi Model-Model Rumit Dalam Penelitian Untuk Skripsi,Tesis Dan Desertasi Doktor. 5thed. Semarang: BP Undip Press.

11. Giovani, Ade Damayanti Vina, and Dini Rosyada. 2019. "Pengaruh Kompetensi Dan Independensi Auditor Terhadap Kualitas Audit Pada Kantor Akuntan Publik Di Makassar." Jurnal Akiun Nabelo 2 (1): 1-15.

12. Hayati, Nur. 2011. "Pengaruh Gender, Tekanan Ketaatan, Kompleksitas Tugas , Pengetahuan Dan Pengalaman Terhadap Audit Judgment." JRAK 2 (2): 43-56. https://doi.org/10.20885/jabis.vol11.iss9.ar $\mathrm{t} 2$.

13. Jamaluddin, and Syarifuddin. 2014. "Ambiguitas Dan Konflik Peran Serta
Independensi Sebagai Determinan Kualitas Audit Internal." Jurnal Akuntansi Multiparadigma 5 (3): 345-510. https://doi.org/10.18202/jamal.2014.12.50 31

14. Messier, Glover, Douglas, and Prawitt. 2008. Auditing And Assurance Services. 6thed. Irwin: McGraw-Hill-Irwin

15. Mulyadi. 2002. Auditing. Jakarta: Salemba Empat

16. Ningsih, A A Putu Ratih, and P Dyan Yaniartha. 2013. "Pengaruh Kompetensi, Independensi Dan Time Budget Pressure

Terhadap Kualitas Audit." E-Jurnal Akuntansi Universitas Udayana 4 (1): 92 109

17. Pektra, Stacia, and Ratnawati Kurnia. 2015. "Pengaruh Gender, Kompleksitas Tugas , Tekanan Ketaatan Dan Pengalaman Auditor Terhadap Audit Judgement." Ultima Accounting $\quad 7 \quad$ (1): $1-20$. https://doi.org/10.1017/CBO978110741532 4.004 .

18. Prihartini, Ayu Kadek, Luh Gede Erni Sulindawati, and Nyoman Ari Surya Darmawan. 2015. "Pengaruh Kompetensi, Independensi, Obyektivitas, Integritas Dan Akuntabilitas Terhadap Kualitas Audit Di Pemerintah Daerah ( Studi Empiris Pada 5 Kantor Inspektorat Provinsi Bali ).” Jurusan Akuntansi Program Univ Pendidikan Ganesha 3 (1): 1-1

19. Rahmina, Listya Yuniastuti, and Sukrisno Agoes. 2014. "Influence of Auditor Independence, Audit Tenure, and Audit Fee on Audit Quality of Members of Capital Market Accountant Forum in Indonesia." Procedia - Social and Behavioral Sciences 164: https://doi.org/10.1016/j.sbspro.2014.11.083

20. Sabil, Ananda Husein. 2019. "Metode Kuantitatif Untuk Penelitian Manajemen (Disampaikan Pada Workshop Analisis Kuantitatif; Konsep Dasar Dan Implementasi Dalam Riset)." Denpasar.

21. Sari, Iis Nurindah, Cipto Wardoyo, and Nujmatul Laily. 2015. "Determinan Kualitas Audit." Journal of Research and 
Applications: Accounting and Management 1

138. https://doi.org/10.18382/jraam.v1i2.23

22. Suseno, Novie Susanti. 2013. "An Empirical Analysis of Auditor Independence and Audit Fees on Audit Quality." International Journal of Management and Business Studies $\quad 3$ (3): 99-109.

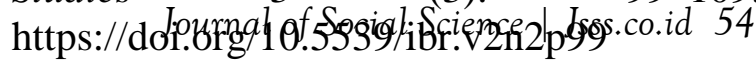

23. Suyono, Eko. 2012. "Determinant Factors Affecting The Audit Quality: An Indonesian Perspective." Global Review of Accounting and Finance 3 (2): 42-57

24. Tarigan, Malem Ukur, and Primsa Bangun Susanti. 2013. "Pengaruh Kompetensi, Etika, Dan Fee Audit Terhadap Kulaitas Audit." Jurnal Akuntansi 13 (1): 803-832
25. Tjun, Lauw Tjun, Elyzabet Indrawati Marpaung, and Santy Setiawan. 2012. "Pengaruh Kompetensi Dan Independensi Auditor Terhadap Kualitas Audit." Journal Akuntansi $\quad 4 \quad$ (1): 33-56. https://doi.org/10.1177/1753193416664491

26. Turley, S, and M Willekens. 2008. Auditing,Trust And Governance;Regulation In Europe. 1sted. England: Oxon Routledge

27. Utami, Ni Made Satya, and I Made Purba Astakoni. 2020. "Peran Gender Sebagai Group Pada Kepemimpinan Path Goal Dan Motivasi Sebagai Determinan Kinerja Guru." Widya Manajemen 2 (1): 36-46. https://doi.org/10.32795/widyamanajemen.v $2 \mathrm{i} 1.548 \mathrm{n}$ 